\title{
Effect of extruded corn flour on the stabilization of biscuit dough for the production of gluten-free biscuit
}

\author{
Tetiana Lisovska ${ }^{1}$, Igor Stadnik ${ }^{1}$, \\ Volodymyr Piddubnyi ${ }^{2}$, Nina Chorna ${ }^{3}$
}

1 - Ivan Puliuy National Technical University of Ternopil, Ternopil, Ukraine
2 - Kyiv National University of Trade and Economics, Kyiv, Ukraine
3 - Kharkiv State University of Food Technology and Trade, Kharkiv, Ukraine

Keywords:

Biscuit

Flour

Corn

Extruded

Stabilization

Article history:

Received 30.06.2019

Received in revised

form 23.12.2019

Accepted 30.03.2020

\section{Corresponding}

author:

Igor Stadnik

E-mail:

igorstadnykk@

gmail.com

DOI: $10.24263 / 2304-$

974X-2020-9-1-14

\section{Abstract}

Introduction. Studies have been carried out to determine the effect of extruded corn flour on the stabilization of the biscuit dough, the indices of the moisture-holding capacity of the flour, foam stability and density of the biscuit dough to create a biscuit semi-finished product for gluten-free food.

Materials and methods. Studies of moisture-holding capacity of flour raw materials were carried out by the method of centrifugation. Foam stability was defined as the ratio of the height to the foam column after holding for 24 hours at a temperature of $18-20^{\circ} \mathrm{C}$ to the total height of the foam column of the sample. Microscopic examination of the structure of the product was performed using a digital binocular microscope series "MicroMed".

Results and discussion. The optimum value of the density of biscuit dough is $0.444-0.446 \mathrm{~kg} / \mathrm{m}^{3}$. Increasing the concentration of extruded corn flour above 20 mass \% leads to a high density of dough, which is undesirable in the production of biscuit semi-finished products, because it makes them denser and less porous. However, the presence of biscuit dough density, at the absence of premium wheat flour, indicates the possibility of creating a gluten-free biscuit semifinished product using solely corn flour. In the sample of the biscuit dough prepared with corn flour extruded 100 mass $\%$ (mass percent), the foam bubbles are of almost the same size, moreover, we can see the formed channels between them that promotes leveling of air pressure inside the foamed biscuit dough. It helps to stabilize the foam. The results of the optimization of the biscuit semi-finished product using extruded corn flour have the following intervals of optimization parameters: replacement of 100 mass\%of wheat flour with extruded corn flour with a quantitative ratio of recipe components "eggs:sugar:flour" 2.1:1:1.02.

Conclusions. Extruded corn flour helps to stabilize the foam biscuit dough system, which allows to create a dietary gluten-free biscuit semi-finished product. 


\section{Introduction}

The effect of extruded corn flour on the stabilization of biscuit dough and the creation of a biscuit semi-finished product for gluten-free food has not previously been described.

The possibility of considering biscuit as a promising product for the development of gluten-free semi-finished product for dietary nutrition was considered. As biscuit dough is a thermodynamically unstable foamy food system, therefore, one of the important technological problems is the stabilization of the system during product formation [1].

A promising way to create gluten-free food is to make deliberate use of ingredients that have a wide range of technological properties. These properties make it possible to improve the structural-mechanical and organoleptic characteristics of the biscuit semi-finished product [2] to correct the nutritional value and, at the same time, to exclude gluten. These types of raw materials include gluten-free cereals and their products [3]. Promising in this aspect is the use of extrusion processing of such raw materials [4].

\section{Literature analysis}

Recent studies have shown that the use of extrudates from soybeans, wheat, rye, corn improves the quality and elastic properties, increases the viscosity of the dough, which increases the volume output of finished products [5;6]. Considering this, it is necessary to study the possibility of using corn extrudate in flour technology in order to stabilize the foam structure of biscuit dough.

There are studies [7-9] based on finding the optimal ratio of structure-forming components for gluten-free flour confectionery. These technologies are based on rice flour and gluten-free starch-protein mixtures. It has been proved [9] that different ratios of protein and starch can be used to adjust the specified quality parameters, such as sugar cookies. However, the possibility of using extruded corn flour, in particular as a source of extruded starch, is warranted.

In the technology of gluten-free bakery products in order to solve the technological problem of the absence of gluten, the use of hydrocolloids and concentrates of animal proteins is proposed to form a foamy structure of gluten-free yeast dough. It was established that the proposed additives in quantities of $0.5-1.0 \%$ of Helios- 11 and $0.5 \%$ of solution of CCSS (carboxymethylcellulose sodium salt) cause $100 \%$ stability of the foam from eggwhite. In this case, the foaming capacity increases only with the addition of Helios-11 in the amount up to $1.0 \%$ and decreases with the higher amount of Helios-11 or in the presence of CCSS. This can be explained by the increase in the density of the whipping mass and the ability of both additives to thicken the solutions [10].

For the production of biscuit semi-finished products, food industry has traditionally used baked wheat flour of the highest grade. Its high technological potential in biscuit dough is not rationally used because it is intended to reduce the "strength" of flour by adding potato starch. A possible solution is the use of extruded corn flour, which is a source of modified starch extrusion and contains gluten-free proteins and can be used in technology of biscuit semi-finished products [11].

The presence of fundamental developments in the production and use of various types of extruded flour in the production of food indicates the possibility of its use in technology of biscuit semi-finished products [12-14].

The purpose of the study is to determine the effect of extruded corn flour on the stabilization of biscuit dough to create a dietary gluten-free biscuit semi-finished product. 


\section{Materials and methods}

Materials under study-extruded corn flour, flour mixtures of premium wheat flour and extruded corn flour, biscuit dough and biscuit semi-finished flour mixtures of wheat flour and extruded corn flour 90:85, 85:15, 80:20, 50:50, 0:100 mass\% [15].

Extruded corn flour is a dry mixture of homogeneous consistency in the form of powder and fine grains with the taste, smell and color inherent in the raw material, made by grinding parts of the grain (endosperm, aleurone layer, fruiting membranes) with pre-removed gastric. The chemical composition of the used extruded corn flour and premium wheat flour are shown in Table 1.

Chemical composition of extruded corn flour and premium wheat flour, $\%$

Table 1

\begin{tabular}{|l|l|l|l|l|l|l|}
\hline Product & $\begin{array}{l}\text { Moisture } \\
\text { content }\end{array}$ & $\begin{array}{l}\text { Protein } \\
\text { content }\end{array}$ & $\begin{array}{l}\text { Fat } \\
\text { content }\end{array}$ & $\begin{array}{l}\text { Starch } \\
\text { content }\end{array}$ & $\begin{array}{l}\text { Ash } \\
\text { content }\end{array}$ & $\begin{array}{l}\text { Fiber } \\
\text { content }\end{array}$ \\
\hline $\begin{array}{l}\text { Extruded } \\
\text { corn flour }\end{array}$ & $9.0 \pm 0.01$ & $6.1 \pm 0.02$ & $8.1 \pm 0.02$ & $70.9 \pm 0.03$ & $4.8 \pm 0.03$ & $1.0 \pm 0.02$ \\
\hline $\begin{array}{l}\text { Premium } \\
\text { wheat flour }\end{array}$ & $14.5 \pm 0.03$ & $11.4 \pm 0.05$ & $1.08 \pm 0.04$ & $67.7 \pm 0.05$ & $0.5 \pm 0.03$ & $0.1 \pm 0.01$ \\
\hline
\end{tabular}

\section{Preparation of prototypes}

A biscuit semi-finished product according to the recipe "Basic" was chosen as a control sample.

The prototyping technology includes the following operations: the egg-sugar mass is beaten to a volume of 2.5-3 times, or about 30-40 minutes. Then the premium wheat flour is gradually added, mixed with starch or extruded corn flour. If the kneading is carried out in a whisking machine, then it should last no more than $15 \mathrm{~s}$.

Ready-made biscuit dough is baked immediately in capsules or cake forms and on sheets, as the biscuit dough settles when stored. Capsules and forms are covered with paper or greased with margarine. Biscuit dough is shaped into $3 / 4$ of their height, as it increases when baking. Biscuit dough is baked at $200-210{ }^{\circ} \mathrm{C}$. Baking time depends on the thickness and volume of the dough. So, in capsules, biscuit is baked 50-60 minutes, in cake forms - 35-40 minutes, on sheets $-10-15$ minutes. The baked biscuit cake is cooled during 20-30 minutes and removed from the molds. The biscuit semi-finished product is left at $8-10$ hours for proofing, after which it is possible to cut it and carry out the following technological operations.

Premium wheat flour is used with a crude gluten content of $23.0 \pm 0.4 \%$ and a crude gluten deformation value of $60 \pm 1.1 \%$, potato starch, chicken eggs, white crystalline sugar (Table 2). 
Table 2

Formulation of experimental samples of biscuit cake (control sample and gluten free product)

\begin{tabular}{|l|l|l|l|l|l|}
\hline Raw materials & \multirow{2}{*}{$\begin{array}{l}\text { The solids } \\
\text { content } \\
\end{array}$} & \multirow{2}{*}{$\begin{array}{l}\text { RC), } \% \\
\text { product, kg }\end{array}$} & $\begin{array}{l}\text { Raw material consumption per 100 kg of semi-finished } \\
\text { Biscuit semi-finished } \\
\text { product (Control sample) }\end{array}$ & \multicolumn{2}{l|}{ Gluten-free biscuit cake } \\
\cline { 3 - 6 } & & real & SC & real & SC \\
\hline $\begin{array}{l}\text { Premium wheat } \\
\text { flour }\end{array}$ & 85.50 & 28.12 & 24.04 & - & - \\
\hline $\begin{array}{l}\text { Corn flour } \\
\text { extruded }\end{array}$ & 91.0 & 8.07 & 7.34 & 30.58 & 27.82 \\
\hline Potato starch & 80.00 & 6.94 & 5.55 & & \\
\hline Chicken eggs & 27.0 & 57.85 & 15.62 & 63.44 & 17.12 \\
\hline White sugar & 99.7 & 34.71 & 34.65 & 30.26 & 30.16 \\
\hline Total & & 135.69 & 87.2 & 124.28 & 75.1 \\
\hline Output & & 100.0 & 87.0 & 100.0 & 75.00 \\
\hline
\end{tabular}

\section{Procedure for conducting research}

\section{Scientific substantiation of technological parameters of biscuit dough stabilization using extrudedcorn flour}

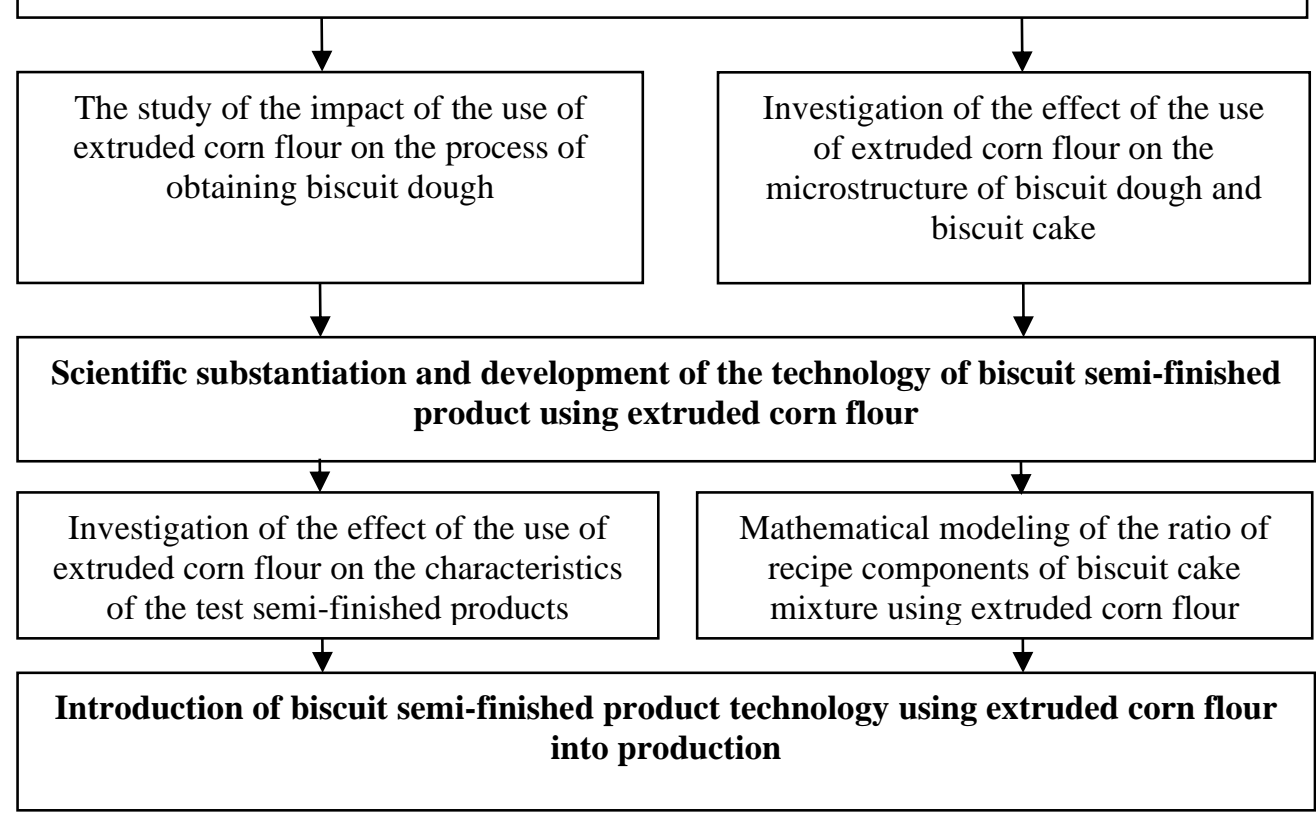




\section{Description of methods}

Studies of moisture retention capacity were carried out by centrifugation. $1 \mathrm{~g}$ of the test sample was weighed into the centrifuge tube, $30 \mathrm{~cm}^{3}$ of distilled water was added, the mixture was stirred for 1 minutes using an electric mixer with a speed of $1000 \mathrm{rpm}$ for 1 minutes. The formed flaking fluid was drained. To remove the residue of water, the tube was tilted onto filter paper, and the tube was weighed after 10 minutes. Water retention capacity (WRC) was calculated by the formula, $\%$

$$
W R C=\left(m_{1}-m_{2} / m\right) \times 100,
$$

where: $m$ - weight of sample, $\mathrm{kg}$;

$m_{1}-$ the weight of the test tube with a dry sample, $\mathrm{kg}$;

$m_{2}-$ wet tube weight, $\mathrm{kg}$.

The foam stability of the egg-sugar mixture with the addition of the flour mixture was determined as the ratio of the height of the foam after ageing for 24 hours at a temperature of $18-20^{\circ} \mathrm{C}$ to the total height of the foam column (FC) of the sample, expressed as a percentage, calculated by the formula:

$$
F S=\frac{H f_{24 \times 60^{2}}}{H f} \times 100 \%
$$

where $F S$ - foam stability, \%;

$H f_{24 \times 60^{2}}$ - height of foam 24 hours after cessation of whipping, m;

$H f$ - initial foam height, $\mathrm{m}$.

Microscopic examination of the structure of the product was performed using a digital binocular microscope series "MicroMed" equipped with a built-in lighting system. The micrographs of the samples were taken at the following magnifications: 40, 100, 400 and 1000 times [17].

The porosity of the samples of the biscuit semi-finished product (control sample) and with extruded corn flour were measured by the effective pore diameters on the biscuit cross sections by visualizing the biscuit microstructure, processing digital images, and based on measurement results [18].

\section{Processing of research results}

Mathematical and statistical analysis. To determine the effect of the ingredients (independent factors xi) on the dough whipping with the appropriate density (optimization parameter G), two-factor experiment was performed with variation of the egg mélange content $(\mathrm{x} 1, \%)$, sugar $(\mathrm{x} 2, \%)$ at fixed flour values $(\mathrm{x} 3, \%)$, that is, determining the magnitude of the density from changes in three main factors: the content of egg mélange (E,\%), sugar $(\mathrm{C}, \%)$ by fixed values of flour $(\mathrm{B} \%), \mathrm{G}=f\left(x_{1}, x_{2}, x_{3}\right)$. Properties of the samples are shown in Table3. 
Table3

Measurements and statistical characteristics of the main indicators of biscuit products during the experiments

\begin{tabular}{|l|l|l|l|l|}
\hline Indicators & \multicolumn{1}{|c|}{ Sample } & \multicolumn{1}{|c|}{$\begin{array}{c}\text { Sample } \\
\mathbf{2}\end{array}$} & $\begin{array}{c}\text { Sample } \\
\mathbf{3}\end{array}$ & $\begin{array}{c}\text { Sample } \\
\mathbf{4}\end{array}$ \\
\hline $\begin{array}{l}\text { Moisture-proofing ability of flour } \\
\text { mixtures, } \%\end{array}$ & $92.0 \pm 5.0$ & $98.0 \pm 3.0$ & $96.0 \pm 3.0$ & $94.0 \pm 4.0$ \\
\hline Density, $\mathrm{kg} / \mathrm{m}^{3}$ & $5.9 \pm 0.6$ & $6.5 \pm 0.5$ & $6.2 \pm 0.6$ & $6.0 \pm 0.6$ \\
\hline Porosity, $\%$ & $80 \pm 8.0$ & $81.5 \pm 5.0$ & $78.0 \pm 7.0$ & $79.0 \pm 7.0$ \\
\hline Weight loss during baking, $\%$ & $12.0 \pm 1.2$ & $10.0 \pm 0.8$ & $12.3 \pm 1.2$ & $11.5 \pm 1.0$ \\
\hline
\end{tabular}

The processing of the obtained data of the results of the experimental are performed according to known methods and methods of statistical processing and regression analysis of experimental results. It is used the differential operators of the program MathCAD-14 to obtain empirical regression equations, which allows to get qualitative and quantitative evaluation of characteristics.

\section{Results and discussion}

\section{Investigation of the moisture-holding capacity of flour mixtures}

The study envisages obtaining a biscuit semi-finished product with complete replacement of premium wheat flour by extruded corn flour. Its technological characteristics and moisture holding capacity in the foaming system were determined.

Table 4 shows the results of the study of the moisture-holding capacity of flour mixtures.

Table4

Comparison of the value of the moisture-holding capacity of flour mixtures

\begin{tabular}{|l|l|c|}
\hline № & \multicolumn{1}{|c|}{ Samples } & $\begin{array}{c}\text { Water retention rate, } \% \\
\text { at } 20 \pm 2^{\circ} \mathrm{C}\end{array}$ \\
\hline 1 & Control sample -100 mass\% of wheat flour & $29 \pm 1.5$ \\
\hline 2 & Wheat flour:extruded corn flour 95:5 mass\% & $38 \pm 1.0$ \\
\hline 3 & Wheat flour:extruded corn flour 90:10mass\% & $49 \pm 2.5$ \\
\hline 4 & Wheat flour:extruded corn flour 85:15 mass\% & $58 \pm 3.0$ \\
\hline 5 & Wheat flour:extruded corn flour 80:20 mass\% & $70 \pm 2.0$ \\
\hline 6 & Wheat flour:corn extruded flour 50:50 mass\% & $81 \pm 1.5$ \\
\hline 7 & Sample with 100 mass\% of extruded corn flour & $93 \pm 4.0$ \\
\hline
\end{tabular}

Table 4 shows that with the increase in the proportion of extrudedcorn flour in the mixture moisture retention capacity increases:for the sample containing 20 mass $\%$ of extruded corn flour by two and a half times, and three times for the sample with extruded corn flour -100 mass\%. This tendency of change, in our opinion, is explained, in particular, by the swelling of whole grains of starch due to the absorption and retention of moisture. The corn starch of extruded corn consists of a part of its whole granules, damaged granules, 
gelatinized starch, polymers of starch [21]. All these components have different effects on the moisture-holding capacity of the flour mixture system. Swollen starch grains are in the middle of the void where water gets. It breaks and weakens some of the hydrogen bonds between the chains, which causes the starch grains to expand, with dissolving the free starch polymers to form a dispersed system [22].

In general, the above-described studies on the moisture-holding capacity of extruded corn flour indicate the feasibility of its use in technology of biscuit semi-finished product. This requires studying the mechanism of the effect of extruded corn flour on biscuit dough components.

\section{Effect of adding extruded corn flour on the density of biscuit dough}

To substantiate the use of extruded corn flour in the production of biscuit semi-finished product and the possibility of complete replacement of premium wheat flour with extruded corn flour, the effect of adding extruded corn flour on the density of biscuit dough was investigated. The average experimental values of the biscuit dough density using extruded corn flour are presented in Figure 1.

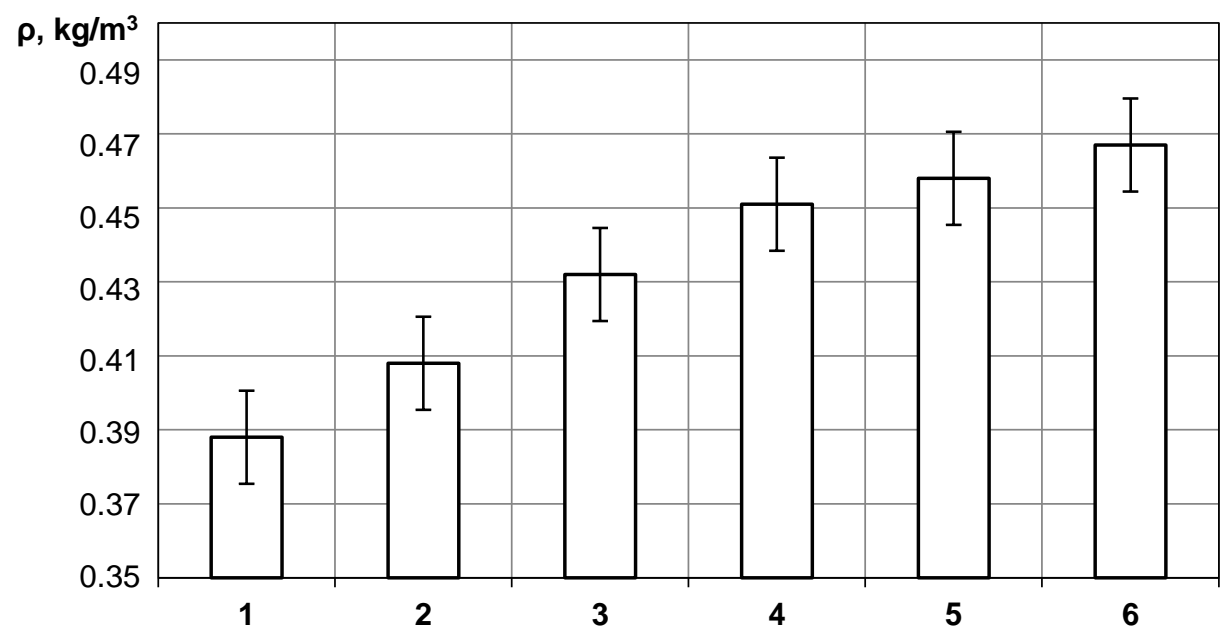

Figure 1. Dependence of biscuit dough density ( $\rho$ ) on ECF content in samples:

1 - (control); 2 -WF:ECF - 95:5 mass \% ; 3 - WF:ECF -90:10 mass\%; 4 - WF:ECF -85:15 mass\% ; 5 - WF:ECF -80:20 mass\%; 6 - WF:ECF - 0:100 mass\%.

Figure 1 shows that with the increase in the proportion of extruded corn flour in the flour mixture, the dough density increases. Optimal value of biscuit dough density is $0.444-$ $0.446 \mathrm{~kg} / \mathrm{m}^{3}$. Increasing the amount of extruded corn flour above 20 mass $\%$ leads to a significant dough density, which is undesirable in the production of biscuit semi-finished products, as it makes them less porous [23]. However, the presence of biscuit dough density, in the absence of premium wheat flour, indicates the possibility of creating a gluten-free biscuit semi-finished product solely using corn flour.

Study of microstructure of biscuit dough 
In the process of production of biscuit semi-finished product, the recipe components undergo physical-chemical transformations and interact with each other to form interconnections, which leads to a change in the microstructure of the semi-finished product. In order to determine the mechanism of stabilization of the foam structure of the biscuit dough with the use of extruded corn flour, the changes in the microstructure of the biscuit dough and the biscuit semi-finished product were studied. The process of making biscuit dough is essentially whipping of the egg-sugar mixture and the dispersion of gas in the liquid. Considering foam as a system that holds air bubbles that are separated only by a thin film of liquid. Schematically, the foam structure can be represented as the packing of gas bubbles with thin films of the basic fine particulate filler [24]. This filler is film-coated with surfactants [25].

Broken mass in the production of biscuit semi-finished product refers to a plasticviscous structured system [23]. Its whipping is accompanied by complex physico-chemical, colloidal and mechanical processes. All of them are aimed at the formation of stable dispersion systems [25]. In order to demonstrate the described structures forming the foam of the biscuit dough (Figure 2), there a comparative characteristic of the microstructure of the following samples is given: wheat flour (WF) and extruded corn flour (ECF) in the ratios: $a-\mathrm{WF}-100$ mass $\%$; $b-\mathrm{WF}: \mathrm{ECF}-80: 20$ mass $\%$; $c$-ECF -100 mass $\%$.

With the introduction of potato starch there is an increase in the plasticity of the dough due to its increased ability to swell and lower retrogradation of starch compared to starch cereals. In control sample ( $a$ ) (Figure 2) it can be seen particles of potato starch, characterized by a large size and oval shape, as well as particles of wheat starch, fractional composition of which is finely dispersed. Sample $(b)$ with a ECF content of 20 mass $\%$ is characterized by the presence of only granules of wheat flour starch. We have proposed a complete replacement of starch and part of premium wheat flour by 20 mass $\%$ of ECF, as well as a complete replacement of wheat flour by ECF for the manufacture of gluten-free biscuit semifinished product.

According to the microstructure of biscuit dough, Figure 4 shows that the structure of the prototype looks like foam. Its structural feature is the presence and uniform distribution of air bubbles, which later forms the porous structure of the biscuit cake. The control sample (a) containing wheat flour and starch shows that the size of the formed air bubbles has a large difference in diameters, that is, some bubbles are almost twice the size of the others. One of the reasons of foam destruction is the diffusion of gas between the bubbles and it is determined by the pressure in the middle of the bubbles [24]. The destruction of the air bubble film is directed towards the larger bubble because its pressure is lower than that of the small bubble [23]. For comparison, in the sample (c)of biscuit dough using ECF of 100 mass\% foam bubbles are almost the same size, in addition, it is noticeable that between them channels of size are formed, which promote the equalization of air pressure in the middle of the foam system of biscuit dough, which promotes the stabilization of the foam system. For epy sample $(b)$ with a content of 20 mass\% of ECF, the same size of gas bubbles is also characteristic, which leads to an improvement in the structural and mechanical characteristics of ready biscuit products. 


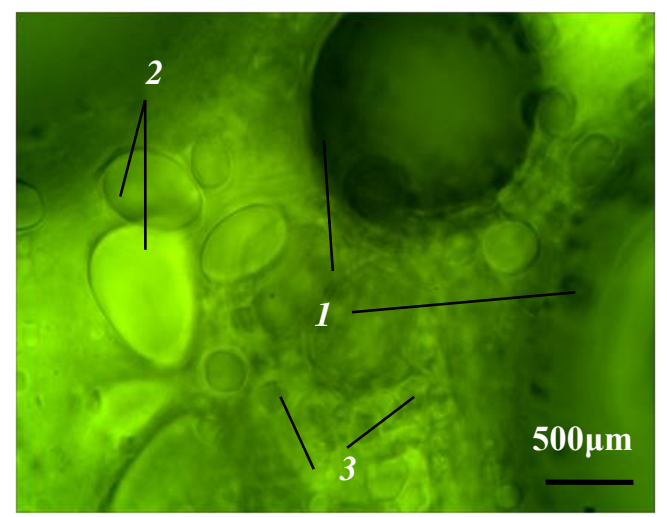

$a$

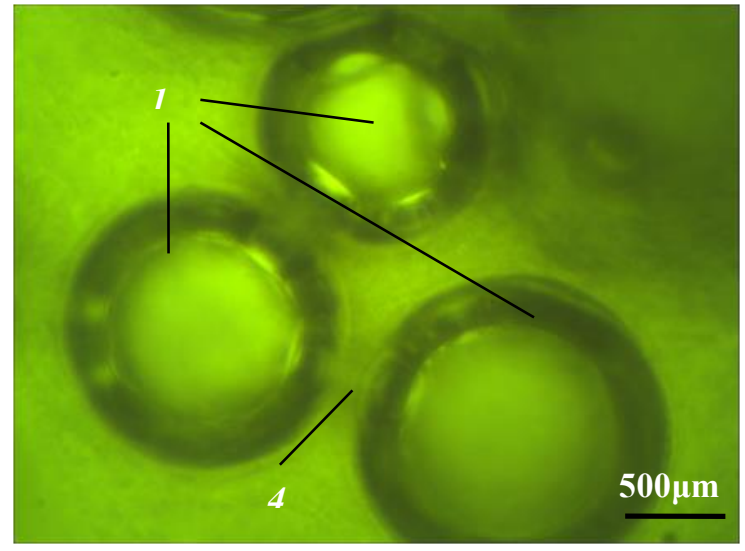

$c$

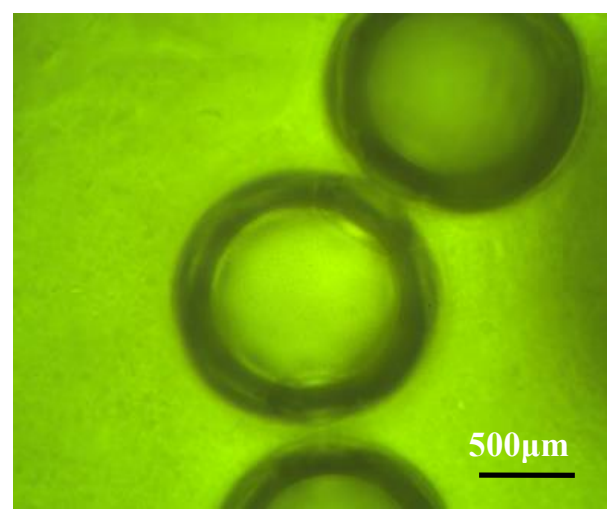

$b$

Figure 2. Microstructure (1:1000) of samples of biscuit dough, containing:

$W F$ and $E C F$ in the ratios:

$a$ - WF - 100 mass\%; $b$-WF:EF - 80:20 mass\%; $c$-ECF - 100 mass\%;

1 - air bubbles; 2 - potato starch grains;

3 - wheat flour starch grains; 4 - channels between air bubbles.

\section{Investigation of the stability of foam biscuit dough}

To determine the role of the liquid phase of the dough during its short storage before baking, the stability of the formed foam was investigated. This value is characterized by the foam settling rate [24]. The results of the study are shown in Figure 3.

Experiments have shown that the stability of the foam depends on the used flour. The introduction of extruded corn flour in the biscuit semi-finished technology helps to reduce the movement of hydrophobic particles, which minimizes their negative impact on the foam stability. High foam stability corresponds to large volume and fine uniform porosity of biscuit cake. 


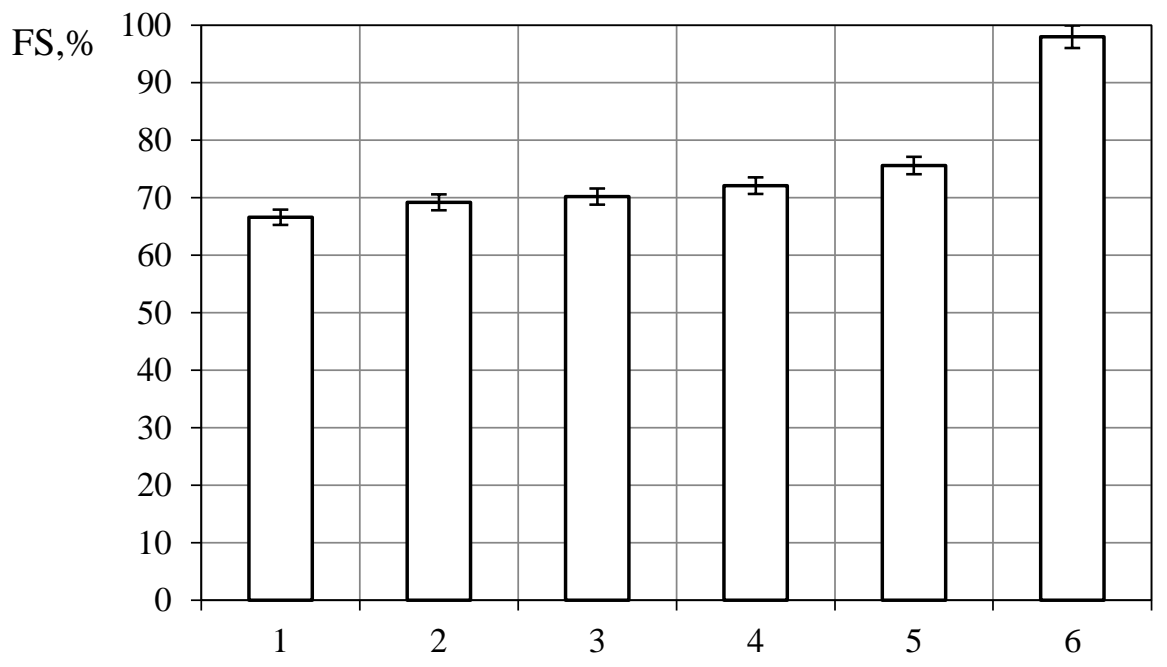

Figure 3. Dependence of biscuit dough foam stability on ECF content: 1 - WF:ECF - 100:0 (control); 2 - WF:ECF - 95:5 mass\%; 3 - WF: ECF - 90:10 mass \% ; 4 - WF:ECF - 85:15 mass \%; 5 - WF:ECF - 80:20 mass\% ; 6 - WF:ECF - 0:100 mass\%

Figure 3 shows that the use of extruded corn flour instead of wheat flour significantly affects the stability of the biscuit dough foam, this indicator monotonically increases almost 1.5 times with the complete replacement of wheat flour. This ability will help to stabilize the foam of the biscuit dough and increase its resistance to mechanical action during its molding.

The use of whipped egg white with sugar forms a stable system that settles rather slowly and gives a small volume. Thus, studies have shown that settling time for the sample 1 is 120 minutes. This phenomenon can be explained by the flocculation caused by the formation of large aggregates and large volume sediment [24].

\section{Study of microstructure of biscuit cake}

After baking (b), a semi-finished biscuit with a volume at the level of the control sample with fine uniform porosity was obtained. The use of extruded corn flour promotes change in the properties of a thick starch paste that becomes gelatinized to produce a viscous dough. Changing the properties of starch when interacting with the emulsifier has a significant impact on the dough system. We see that the formation of a fine-porous structure of biscuit dough using 20 mass\% and 100 mass\% of extruded corn flour is due to the properties of the starch of extruded flour.

In Figure 4 it can be seen that the structure of the biscuit semi-finished product looks like a spatial grid. The results of the study indicate the presence and uniformity of pore distribution in samples $b$ and $c$ using extruded corn flour, which is an integral part of the porous structure of the biscuit cake. 


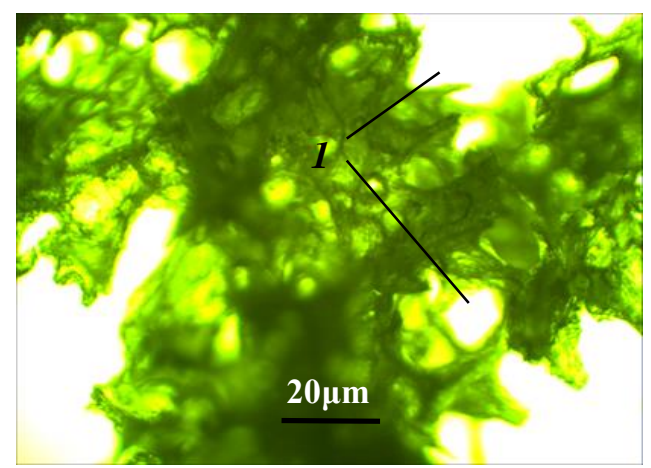

$a$

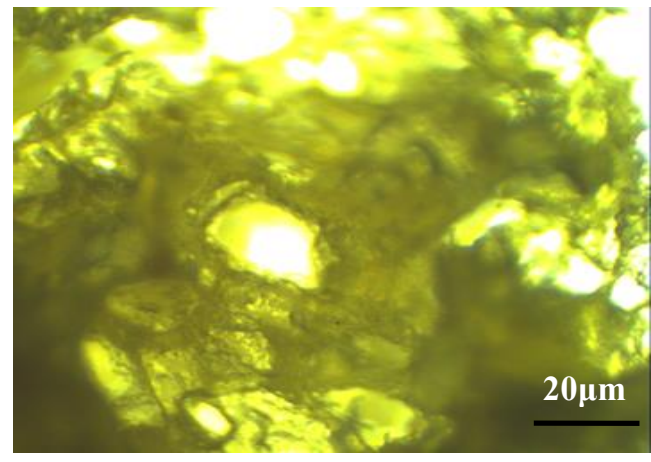

$b$

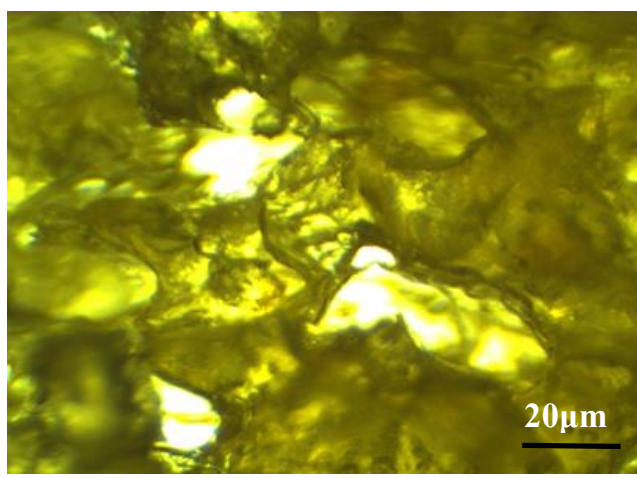

$c$

Figure 4. Microstructure (1:40) of samples of biscuit semi-finished product containing: WF and ECF in the ratios:

$A-\mathrm{WF}-100$ mass \%; $b$ - WF:ECF - 80:20 mass \%; $c$ - ECF - 100 mass \%;

1 - pores.

Therefore, the effect of extruded corn flour on the properties of biscuit dough and biscuit cake is caused first of all by the properties of corn flour starch that has undergone extrusion treatment. Using the obtained results allows to recommend extruded corn flour for the production of gluten-free biscuits for dietetic nutrition.

The results of the studies showed that it is advisable to have 100 mass\% substitution of wheat flour for corn flour extruded in biscuit semi-finished technology. During the experimental research, measurements of the basic characteristics of the biscuit were performed and their statistical analysis was performed. 


\section{Comparison of the porosity of the obtained samples of biscuit cake}

The porosity of the samples of the biscuit semi-finished product (control sample) and sample with extruded corn flour were carried out by measuring the effective pore diameters on the biscuit cross sections (Figure 5), by visualizing the biscuit microstructure, processing the digital images and measuring them.

The processing of the research results allowed to obtain color gradient matrices on fragments of biscuit images with extruded corn flour. All selected fragments observed the presence of areas of high gradient values of the digital image brightness matrix around the in homogeneities (inclusions, pores, areas with variable humidity). They also observed the indicated areas with slightly smaller maximum values of the structural characteristics gradient compared to the trivial materials in the matrix around the air inclusions or included particles. This has shown that structural changes occur to a less extent and are explained by the formation of super molecular structures in the form of globular aggregates of macromolecules, both around the air inclusions and in the volume of the matrix, indicating the formation of a heterogeneous structure [25]. Within the two-factor model, the method of modeling moisture content, density, porosity and sintering from the content of egg melange, sugar and extruded corn was used.

A program for calculating the parameters of a quadratic biscuit density dependence model $\mathrm{G}\left(\mathrm{kg} / \mathrm{m}^{3}\right)$ from the content (\%) of ingredients: E (egg product), C (sugar) and B (flour) according to the results of tests for 4 samples, characterized by the sets of content of ingredients is are given in. Accordingly, the density dependence and its possible absolute and relative error were evaluated.

$$
\begin{aligned}
& \mathrm{g}_{1}=5.9 \quad \mathrm{~g}_{2}=6.5 \quad \mathrm{~g}_{3}=6.2 \quad \mathrm{~g}_{4}=6 \\
& \mathrm{sg}_{1}=0.6 \quad \mathrm{sg}_{2}=0.5 \quad \mathrm{sg}_{3}=0.6 \quad \mathrm{sg}_{4}=0.6 \\
& \mathrm{G}=\left(\begin{array}{l}
g_{1} \\
g_{2} \\
g_{3} \\
g_{4}
\end{array}\right) \quad \mathrm{E}=\left(\begin{array}{l}
e_{1} \\
e_{2} \\
e_{3} \\
e_{4}
\end{array}\right) \quad \mathrm{C}=\left(\begin{array}{l}
c_{1} \\
c_{2} \\
c_{3} \\
c_{4}
\end{array}\right) \quad \mathrm{\textrm {y } _ { 1 } = 0 . 5} \quad \mathrm{y}_{2}=0.5 \quad \mathrm{~B}=0.5 \quad \text { Given } \\
& \text { G- } g_{2}=y_{1}\left(E-e_{2}\right)^{2}+y_{2}\left(C-e_{2}\right)^{2}+y_{3}\left(B-b_{2}\right)^{2}
\end{aligned}
$$

The last relation gives an opportunity to obtain a polynomial formula for further studies: $G(E, C, B)=102.25 \cdot C-87.66 \cdot C \cdot B-165.12 \cdot C^{2}-143.25 \cdot B^{2}+145.88 \cdot B-37.08$.

The calculation of the absolute $d G$ and relative $\delta G$ the error of the density $G$ of the biscuit product makes itpossible to state that the maximum density of the biscuit product is reached for the parameters $(\mathrm{E}, \mathrm{C}, \mathrm{B})=(0.5 ; 0.23 ; 0.23)$ with a high level of accuracy $-1.4 \%$

The MathCAD operator of the extremum estimate for the function $\mathrm{G}(\mathrm{E}, \mathrm{C}, \mathrm{B})$ gives the maximum density result: $\max (\mathrm{g})=6.47\left(\mathrm{~kg} / \mathrm{m}^{3}\right)$ Figure 5 . The third parameter $\mathrm{B}-$ the content of the flour is not clearly affected, based on the condition: $\mathrm{E}+\mathrm{C}+\mathrm{B}=1$. 


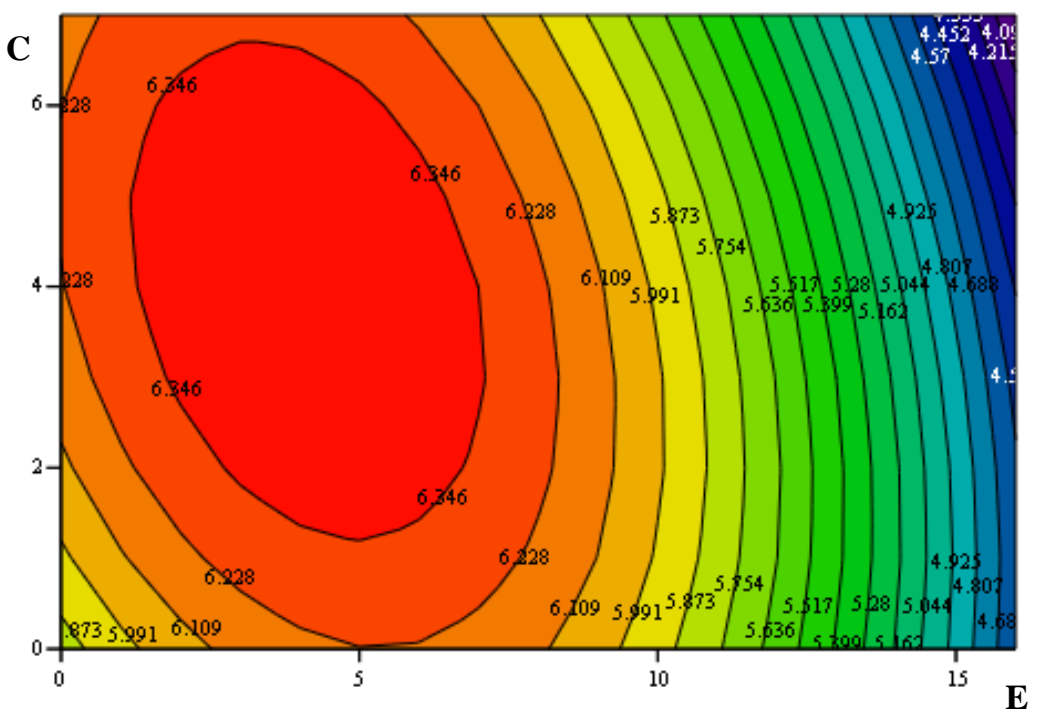

Figure 5. Density levels of biscuit $G$ with respect to parameters $E$ and $C$

Similarly, to the results of the program of calculating the parameters of the quadratic model of density dependence on the content of ingredients using MathCAD-14, analytical expressions were obtained representing the dependence of indices of absorption (U), porosity (P) and moisture content (V) on the parameters of egg content (E), sugars (C) and flour (B).

$$
\begin{aligned}
& V(E, C, B)=13.06 \cdot E+0.61 \cdot C+2.31 \cdot B-13.11 \cdot E^{2}-1.31 \cdot C^{2}-4.97 \cdot B^{2}-2.61 \\
& U(E, C, B)=-3.38 \cdot E-2.88 \cdot C+3.38 \cdot E^{2}+6.27 \cdot C^{2}+11.18 \\
& P(E, C, B)=625 \cdot E-625 \cdot E^{2}-2393 \cdot C^{2}+1100.78 \cdot C-2339.0 \cdot B^{2}+1263.06 \cdot B-371.85
\end{aligned}
$$

Analytical expressions make it possible to state that the optimum density of biscuit semi-finished product is achieved for the parameters $(\mathrm{E}, \mathrm{C}, \mathrm{B})=(0.5 ; 0.24 ; 0.24)$ with a high level of accuracy $-1.4 \%$ (Figure6).

The operator of the MathCAD program of extremum estimation for the function $\mathrm{G}(\mathrm{E}$, $\mathrm{C}, \mathrm{B})$ gives the optimality result: $\max (\mathrm{V})=98 \%, \min (\mathrm{U})=10 \%, \max (\mathrm{P})=81.1 \%$. Note that the analytical expression of the dependence of the biscuit packing does not contain parameter B (flour content).

Analysis of diagrams (Figure 6) of biscuit product parameters gives reason to claim that the found optimum corresponds to the values of the content of ingredients: egg $-50 \%$, sugar $-23 \%$, flour $-27 \%$ with accuracy: $0.4,0.14$ and $0.12 \%$ respectively.

According to the results of the optimization of biscuit cake with the use of extruded corn flour has the following optimization intervals: 100 mass $\%$. That is, at $x 1(E)=51 \%$, $\mathrm{x} 2(\mathrm{C})=24.4 \%$, and ECF content of $24.6 \%$ with accuracy: $0.4,0.14$ and $0.12 \%$ respectively, with the best performance of sintering, porosity, dough density and moisture content.

The mathematical processing of the results of the study allowed to optimize the main recipe components of the biscuit semi-finished product, called "Gluten-free" and to determine their optimal ratio - eggs:whitesugar:ECF - 2.1:1:1.02. 

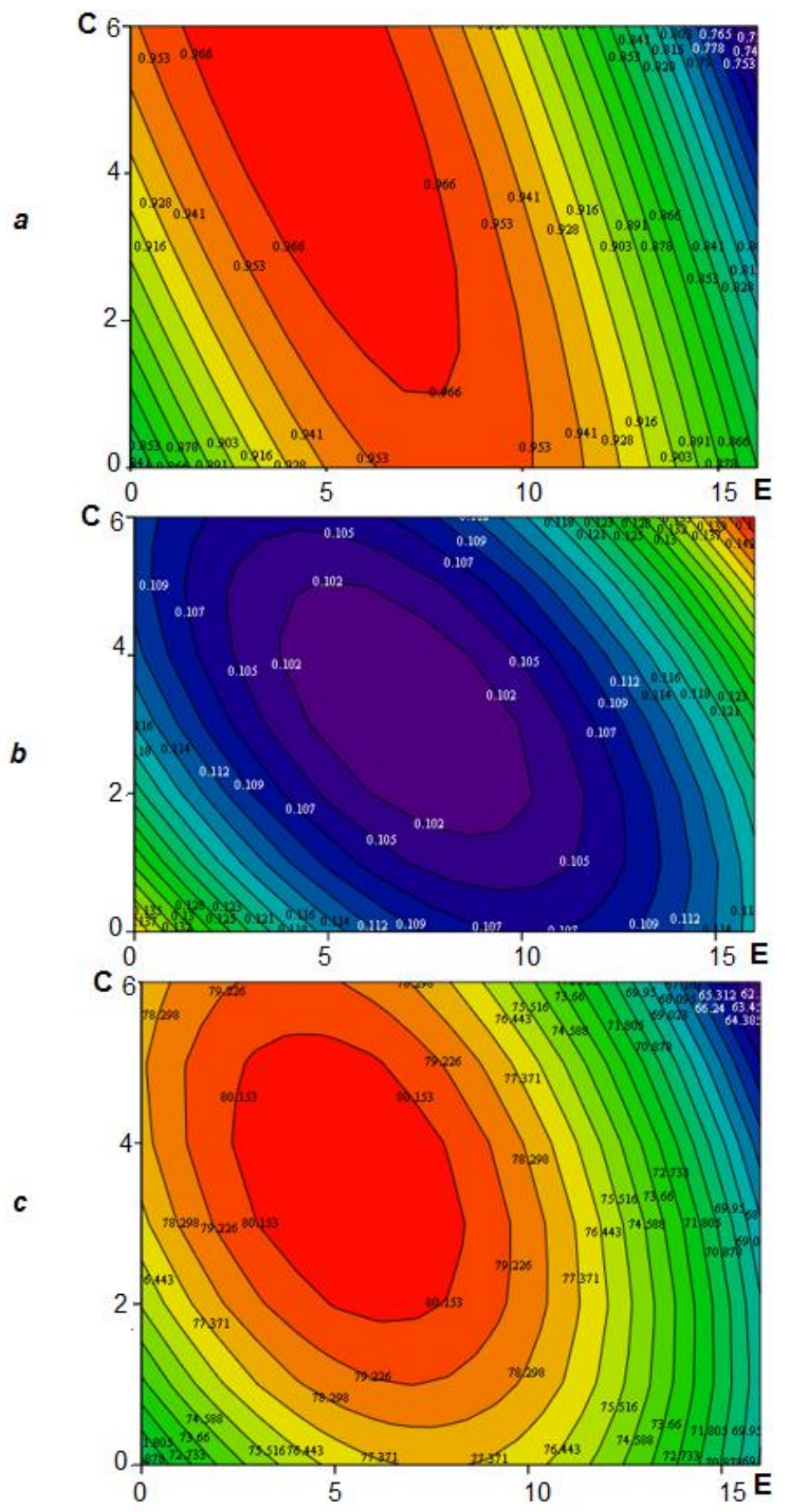

Figure 6. Effect of content of egg $E$ and sugar $C$ on moisture content $V$ (figure 6a), indices of absorption $U$ (figure $6 b$ ) and porosity $P$ (figure $6 c$ ) of the biscuit 


\section{Conclusions}

As a result of solving the research problems, new scientific results were obtained, which are as follows:

1. The stabilization of the rheological properties of the foam system of biscuit gluten-free dough is achieved due to the properties of partially gelatinized starch of extruded flour.

2. Optimized formulation of gluten-free biscuit based on $100 \%$ replacement of wheat flour with extruded corn flour with a quantitative ratio of recipe components "eggs: sugar: ECF" 2.1:1:1.02. The ratio of the main recipe components is: egg content $-51 \%$; sugar content $-24.4 \%$ and content of extruded corn flour- $24.6 \%$.

3. The conducted research is the technological basis for the development of a wide range of food products with improved organoleptic characteristics for special dietary nutrition.

\section{References}

1. Brent S. Murray (2007), Stabilization of bubbles and foams, Current Opinion in Colloid \& Interface Science, 12(4-5), pp. 232-241, DOI: 10.1016/j.cocis.2007.07.009

2. Jun Liu Stefan, Will för Chunlin Xu A (2015), Review of bioactive plant polysaccharides: Biological activities, functionalization, and biomedical applications, Bioactive Carbohydrates and Dietary Fibre, 5(1), pp. 31-61, DOI: 10.1016/J.BCDF.2014.12.001

3. Kobets O., Dotsenko V, Arpul O., Dovgun I. (2015), Wheat fibre impact on flour quality of confectionery products, Journal Food and Environment Safety, 14(4), pp. 391-398.

4. Stojceska V., Ainsworth P., Plunkett A.,. İbanoğlu Ş. (2010), The advantage of using extrusion processing for increasing dietary fibre level in gluten-free products, Food chemistry, 121(1), pp. 156-164, DOI: 10.1016/J.FOODCHEM.2009.12.024

5. Drobot V.I., Pysarets O.P., Kravchenko I.M. (2013), Vykorystannia kukurudzianoi krupy u vyrobnytstvi pshenychnoho khliba, Khranenye y pererabotka zerna, 9, pp 53-55.

6. Brekhov A.F, Riazhskykh V.Y., (2012), Prohnozyrovanye byolohycheskoiy pyshchevoi tsennosty v hotovoi produktsyy pryekstruzyonnoi obrabotke rastytelnoho syria, Khranenye y pererabotka selkho zsyria, 3, pp. 38-42.

7. Yehorov B. V., Mardar M. R., Bordun T. V. (2014), Formuvannia spozhyvnykh vlastyvostei kharchovykh produktiv novoho pokolinnia shliakhom ekstruzii, Khranenye y pererabotkazerna, 5(182), pp. 64-67.

8. Renzjaeva T. V., Bakirova M. E., (2017), Pechen'e iz risovoj muki dlja specializirovannogo pitanija. Tehnologii pishhevoj i pererabatyvajushhej promyshlennosti APK-produkty zdorovogo pitanija, 1, pp. 49-54.

9. Camino M., Mancebo Patricia Rodriguez, Manuel Gómez (2016), Assessing rice flour-starchprotein mixtures to produce gluten free sugar-snap cookies, LWT-Food Science and Technology, 67, pp. 127-132.

10. Haliasnyi, I., T. Gavrish, and O. Shanina (2018), Research of surface properties of water-flour suspensions in the presence of hydrocolloids and protein supplements. Technology audit and production reserves, 1(3(39), pp. 58-63.

11. Lisovskaja T. O., Chernaja N. V. (2013), Issledovanie aminokislotnogo sostava belkov muki kukuruznojj ekstrudirovanoj, Tehnika tehnologija pishhevyh proizvodstv: sb. nauch. trud., 1, pp. 144.

12. Rus'kina A.A., Popova N.V., Naumenok N.V., Rus'kin D.V. (2017), Analiz sovremennyh sposobov modifikacii krahmala kak instrumenta povyshenija ego tehnologicheskih svojstv, Bulletin of the South Ural State University. Ser. Food and Biotechnology, 5 (3), pp. 12-20. 
13. Holovchenko V., Lopatin H., Kovbasa V.M. (2001), Ekstrudaty, shrot i kontsentratyi z zernobobovykh mozhna vykorystovuvaty dlia stvorennia novykh vydiv kharchovykh produktiv, Kharchova i pererobna prom., 1, pp. 23-25.

14. Dickinson E (2015), Colloids in food: ingredients, structure, and stability, Annual review of food science and technology, 6, pp. 211-233.

15. Zeng J., Gao H., Li G., Liang X. (2011), Extruded corn flour changed the functionality behaviour of blends, Czech J. Food Sci., 29, pp. 520-527.

16. Yu, L., Ramaswamy, H.S. \& Boye, J. (2012), Twin-screw Extrusion of Corn Flour and Soy Protein Isolate (SPI) Blends: A Response Surface Analysis, Food Bioprocess Technol, 5, pp. 485497, DOI: 10.1007/S11947-009-0294-8.

17. (2012), An Introduction to Microscopy by Means of Light, Electrons, X-Rays, or ultrasound. Eugene Rochow, p. 367.

18. Igor Stadnyk, Volodymyr Piddubnuy, Olena Eremeeva, Halyna Karpyk (2018), Features of heat transfer in the environment when it is sprayed with rotary rollers, Potravinarstvo Slovak Journal of Food Sciences, 12(1), pp. 824-835, DOI: 10.5219/977

19. Kovalenko A.A. (2010), Tekhnolohiia desertiv z vykorystanniam stabilizatsiinykh system naosnovi krokhmaliu: monohrafiia, Kharkiv.

20. Victoria Dorohovych, Mariia Hrytsevich, Nataliia Isakova (2018), Effect of gluten-free flour on sensory, physico-chemical, structural and mechanical properties of wafer batter and waffles, Ukrainian Food Journal, 7(2), pp. 253-263

21. Dickinson E. (2015), Colloids in food: ingredients, structure, and stability, Annual review of food science and technology, 6, pp. 211-233.

22. Lopez O.V. et al. (2013), Acetylated and native corn starch blend films produced by blown extrution, Jornal of Food Engineering, 21(1), pp. 1-22.

23. Lisovska T., Chorna N., Dyakov A. (2016), Research of rheological properties of egg sponge with extruded corn flour, Eastern-European Journal of Enterprise Technologies 2, 11(80), pp. 19-23.

24. Murray B.S., Ettelaie R. (2004), Foam stability: Proteins and nanoparticles, Current Opinion in Colloid and Interface Science, 9(5), pp. 314-320.

25. Ali J. Green, Karen A. Littlejohn, Paul Hooley, Philip W. Co x. (2013), Formation and stability of food foams and aerated emulsions, Hydrophobins as novel functional ingredients, Current Opinion in Colloid \&Inter face Science, 18, pp. 292-301.

26. Pyvovarov P. P., Zakharenko V. O., Troshchyi T. V. (2012), Udoskonalennia metodolohii ekspertyzy poruvatykh kharchovykh produktiv: monohrafiia, Kharkiv. 